\title{
KIF1B Gene
}

National Cancer Institute

\section{Source}

National Cancer Institute. KIF1B Gene. NCI Thesaurus. Code C152002.

This gene plays a role in localization of mitochondria and transport of synaptic vesicles. 